\title{
Zmienne w relacjach politycznych Unii Europejskiej z Egiptem po roku 2012 ${ }^{1}$
}

\section{Wprowadzenie}

Po roku 2012 stan relacji egipsko-unijnych jest determinowany wydarzeniami arabskiej wiosny, które wpłynęły na stan obecnej sytuacji polityczno-gospodarczej Egiptu. Unijna strona musiała zmienić swoje dotychczasowe założenia dotyczące współpracy z Egiptem i stworzyć nowe ramy instrumentów oddziaływania w szerszej skali regionu Afryki Północnej i Bliskiego Wschodu. Stanowią one podstawę trudnego kompromisu dla obu stron. Unijna strona jest świadoma konieczności pozostania aktywnym graczem w Egipcie gdzie widoczne są interesy polityczne i gospodarcze jej poszczególnych państw członkowskich. Płaci za to cenę ustępstw w promowaniu wartości, które uznaje za standard. Niestabilność sytuacji w Egipcie, czynią wyrażaną w deklaracjach politycznych i uwidocznioną w rolach, które pragnie pełnić w regionie powinność unijną za niezwykle trudną w realizacji. Co ważne, europejska wizja wspólnych relacji nie znajduje odzwierciedlenia w potrzebach i oczekiwaniach strony egipskiej. Konsekwencją tego jest duży opór we wdrażaniu wielu instrumentów wsparcia, które Unia oferuje partnerowi.

Celem artykułu jest ukazanie zmiennych określających ramy polityki Unii wobec Egiptu po roku 2012, a także analiza zakresu nowego podejścia do kształtowania wzajemnych relacji w ich wymiarze politycznym. Szczególna uwaga skupiona została na mechanizmie zastosowania instrumentów poszczególnych polityk unijnych na tle wydarzeń na scenie politycznej Egiptu. Powyższe rozważania pozwolą na przedstawienie wniosków dotyczących dalszych możliwości prowadzenia działań przez Unię Europejską w określonych ramach współpracy z Egiptem, biorąc pod uwagę konieczność ustalania wspólnych interesów, jak i wdrażania wypracowanego stanowiska.

\section{Rok nadziei na zmiany w relacjach UE-Egipt}

Po roku 2011 Europejska Polityka Sąsiedztwa pozostała swoistą bazą na której Unia Europejska budowała płaszczyznę politycznych oddziaływań w relacjach z Egip-

\footnotetext{
Artykuł jest poszerzoną wersją elementu analizy przygotowanej w ramach projektu badawczego pt. Unia Europejska wobec procesów transformacyjnych w Egipcie po 2011 roku, realizowanego na Wydziale Nauk Politycznych i Dziennikarstwa UAM, finansowanego przez Narodowe Centrum Nauki (NN 2012/05/B/HS5/005).
} 
tem. Jednakże zmiany na scenie politycznej w Egipcie nie zostały ukierunkowane w celach, które byłyby dobrze odebrane przez stronę europejską. Rok 2012 był okresem nadziei na zmiany korzystnie wpływające na obustronne relacje. Transformacja polityczna wymuszała na stronie europejskiej podejmowanie szybkich decyzji gwarantujących utrzymanie dotychczasowej uprzywilejowanej pozycji w relacjach. Po wydarzeniach arabskiej wiosny postęp w implementacji reform stał się nieprzewidywalny dla partnerów. W pierwszych miesiącach po przewrocie odżyły aspiracje każdej ze stron politycznej sceny. Dążenie do transformacji i pozytywnych przemian w państwie było bardzo silne. Jednakże ich kierunek dzielił Egipcjan. W deklaracjach unijnych pojawiła się nadzieja, że Egipt, pomimo trudności, będzie kontynuował wdrażanie konstytucyjnych reform.

Za rządów Najwyższej Rady Wojskowej do 2 czerwca 2012 r. toczył się proces Hosni Mubaraka oraz jego synów. Mubarak został skazany na karę dożywotniego więzienia za współudział w śmierci kilkuset demonstrantów. Pierwsza połowa 2012 r. zdominowana została kampanią wyborczą. Początkowo zaplanowano wybory na kwiecień, później ich datę przesunięto na maj i czerwiec 2012 r., co także wywołało demonstracje, gdyż społeczeństwo egipskie domagało się jak najszybszego transferu władzy.

Początek roku 2012 to czas intensywnej pracy w instytucjach Unii nad ramami wdrożenia postanowień z drugiej połowy roku 2011. W maju 2012, Komisja Europejska wydaje komunikat zatytułowany „Realizacja nowej europejskiej polityki sąsiedztwa", w którym potwierdzono nowe otwarcie w relacjach z państwami ENP słowami: „polityka opiera się na nowych zasadach, w tym «więcej za więcej», wzajemnej odpowiedzialności między UE a jej partnerami, partnerstwie nie tylko ze stroną rządową, ale także ze społeczeństwem obywatelskim (np. organizacjami pozarządowymi, przedsiębiorstwami, środowiskiem akademickim, mediami, związkami i grupami religijnymi) i uznaniu szczególnej roli kobiet w przekształcaniu politycznym i społecznym" (European Commission, 2012a). Podkreślonym elementem w tym tzw. nowym podejściu jest zasada zróżnicowania i relacji na miarę potrzeb i ambicji partnerów (ang. tailors relations). Zróżnicowanie zapewnia dostrzeżenie ograniczeń występujących w konkretnych państwach. Takie założenie miało w przyszłości uniemożliwić zablokowanie wdrożenia regionalnego ujęcia zaproponowanego przez UE (Greenfielg, Balfour, 2012). Na forum Unii uwidocznione zostaje przekonanie, że rozpoczyna się długi proces walki o ugruntowanie pozycji w poszczególnych państwach, a rozpoczęte przeobrażenia w świecie arabskim nie będą w równym stopniu odczuwalne we wszystkich państwach regionu. Sytuacja w wielu z nich może ulec pogorszeniu od tej sprzed roku 2011. Unia traci dotychczasowych interlokutorów rozmów, partnerów współpracy. Egipt jest przykładem państwa, gdzie bardzo widoczne staje się to, że Unia musi na nowo stworzyć sieć powiązań. Nowe władze są niechętne nawiązaniu bliższych relacji i ram współzależności, chcą renegocjować wcześniejsze zobowiązania, żądają nowych obietnic.

Podczas spotkania ministrów spraw zagranicznych w lipcu 2012 r. potwierdzono podstawę do prowadzenia i monitorowania dalszej realizacji celów Partnerstwa poprzez określenie partnerów kluczowych i opisywanie tego, co UE może zrobić i jakie wsparcie może zaoferować. Plan przedstawia koncepcję wzajemnej odpowiedzialności i współodpowiedzialności (Council, 2012; Joint Communication, 2012). 
Okres 2012-2013 to czas porewolucyjnego kryzysu politycznego w Egipcie, który charakteryzuje się antyrządowymi protestami o charakterze politycznym, zmianą rządu, destabilizacją sceny politycznej, licznymi manifestacjami, których podłożem jest bunt wobec istniejącej sytuacji. Nowy prezydent Mursi zaprzysiężony zostaje na stanowisko 30 czerwca $2012 \mathrm{r}$. W pierwszych wystapieniach zobowiązuje się do powołania szerokiego rządu, złożonego z przedstawicieli rożnych środowisk społecznych. 16 czerwca 2012 r. Najwyższa Rada Sił Zbrojnych w wydanym dekrecie oficjalnie rozwiązuje Zgromadzenie Ludowe, gdyż Sąd Najwyższy podjął decyzję o unieważnieniu wyborów parlamentarnych i przeprowadzeniu nowego głosowania, gdyż odbyło się ono w sprzeczności z konstytucją. Najwyższa Rada Sił Zbrojnych ogłosiła, że Tymczasowa Deklaracja Konstytucyjna, ogranicza kompetencje prezydenta. Nowe wybory parlamentarne mogły być zorganizowane dopiero po uchwaleniu nowej konstytucji. Jednak prezydenckim dekretem z 8 lipca 2012 r., Muhammad Mursi przywrócił skład zdominowanego przez islamistów parlamentu, a 24 lipca 2012 r. desygnował na urząd premiera.

Od 2012 roku UE konsekwentnie starała się wspierać ruch na rzecz demokracji i praw człowieka w Egipcie, wzywając do pokojowych działań (Crawford, 2013). Egipt stał się miejscem wizyt przedstawicieli instytucji Unii, Przewodniczącego Komisji Europejskiej José Manuel Barroso, Przewodniczącego Rady Europejskiej Hermana Van Rompuy, komisarza ds. polityki sąsiedztwa Stefana Füle Wysokiej Przedstawiciel Catherine Ashton. Szczególnie ta ostatnia podjęła się szeregu działań na rzecz odnowienia relacji z wybranym prezydentem Mursim w ten sposób legitymizując i wspierając jego działania. Nowy egipski prezydent jako jeden z pierwszych celów wizyty zagranicznej w roku 2012 obral instytucje brukselskie. Jego wizyta 13 września 2012 roku zaowocowała porozumieniem stanowiącym wznowienie kontaktów dwustronnych poprzez struktury Układu o stowarzyszeniu UE-Egipt i ponownym uruchomieniu negocjacji w sprawie nowego planu działania w ramach Europejskiej Polityki Sąsiedztwa. Po roku 2011 Unia skupiła swoje środki na działaniach na rzecz transformacji demokratycznej w Egipcie, rozwoju społeczeństwa obywatelskiego, praworządności, praw człowieka, oraz przede wszystkim przejrzystości i efektywności procesu wyborczego, w tym poprzez zapewnianie doradztwa technicznego i prowadzenie wspólpracy technicznej oraz rozmieszczanie misji obserwacji wyborów. UE udzieliła także pomocy technicznej władzom przy zorganizowaniu wyborów w Egipcie. Wysłano w tym celu dwóch ekspertów do oceny przebiegu wyborów w maju/czerwcu 2012 roku. Z tych środków wspierano również organizacje społeczeństwa obywatelskiego w podnoszeniu świadomości społecznej i przeprowadzono szkolenia krajowych obserwatorów wyborów.

\section{Efekty dzialań Grupy Zadaniowej Unia Europejska-Egipt}

Niezwykłym, jak na dotychczasową praktykę relacji było spotkanie szerokiego grona partnerów w Kairze 14 listopada 2012 r. Ta nowa platforma dialogu pod nazwą grupy zadaniowej (ang. EU-Egypt Task Force) miała być innowacyjną formą dyplomacji europejskiej skierowanej do państw w procesie transformacji. Grupa zadaniowa, której przewodziła m.in. Wysoka Przedstawiciel, wiceprzewodnicząca Komisji Europejskiej 
Catherine Ashton. Grupa stała się nowym narzędziem europejskiej polityki. Jej celem było zwiększenie zaangażowania UE w państwach będących w okresie transformacji poprzez mobilizację wszystkich aktywów UE i współpracę z sektorem publicznym, prywatnym, jak i pozarządowym w Egipcie. Do osiągnięć grupy zadaniowej należy zaliczyć koordynację przyszłych inwestycji w ramach instytucji UE, państw członkowskich, EBI i EBOR-u. Na spotkaniu poruszono także temat wytycznych negocjacyjnych dla kompleksowych umów o wolnym handlu (ang. DCFTA) (EU, 2012). Ustalono także dodatkowe środki finansowe wspierające rozwój gospodarczy Egiptu. Komisja ogłosiła rozpoczęcie wdrażania inicjatywy w celu poprawy wydajności produkcji rolnej i rozwoju wsi (ENPARD). Podstawowym założeniem grupy zadaniowej było zaproszenie do dialogu jak największej liczby partnerów społeczno-gospodarczych różnych sektorów publicznego, prywatnego i pozarządowego. Kairskie spotkanie zgromadziło ponad 500 przedstawicieli instytucji i różnych środowisk życia społeczno-gospodarczego. Wśród nich znalazło się ponad 100 europejskich i 200 egipskich przedsiębiorców. Na tym spotkaniu potwierdzano wielokrotnie hasło ,nowej ery w relacjach między UE i Egiptem jako równych partnerów i bliskich sojuszników ze wspólnymi aspiracjami i wartościami" (EU-Egypt Task Force, 2012). Jak się okazało deklaracje były płonne i już za kilka miesięcy sytuacja miała się diametralnie zmienić.

Na potrzeby nawiązania więzi z nowymi władzami uruchomiono także dodatkowa pulę środków finansowych. W zakresie wsparcia finansowego UE zadeklarowała początkowo $449 \mathrm{mln}$ euro na lata 2011-2013. W tym też okresie udało się uruchomić środki z EBI i EBOR. Całościowy pakiet finansowy zadeklarowany podczas szczytu listopadowego grupy zadaniowej UE-Egipt wynosił 5 mld euro. W nim znalazło się $750 \mathrm{mln}$ unijnego wkładu ${ }^{2}$. Wkład ten stanowiły także środki z programu SPRING w wysokości $90 \mathrm{mln}$ euro, przeznaczone na wsparcie, we współpracy z innymi darczyńcami np. Bankiem Światowym i Afrykańskim Bankiem Rozwoju, programu społeczno-gospodarczego rządu (EU, 2011). Najważniejszym sukcesem grupy zadaniowej UE i Egiptu było osiągnięcie zgody, aby wspólnie działać na rzecz pogłębienia stosunków handlowych i inwestycyjnych, w tym możliwości negocjacji kompleksowej umowy o wolnym handlu (European Commission, 2013).

22 listopada 2012 r. Muhammad Mursi wydał dekrety, które rozszerzyły jego kompetencje. Z dekretów wynikało, że do czasu opracowania nowej egipskiej konstytucji, żaden organ w tym Sąd Najwyższy, nie może ograniczyć jego decyzji. Dekrety umożliwiały procesy wysokich urzędników z czasów rządów Mubaraka, zakazywały rozwiązywania Zgromadzenia Narodowego do czasu opracowania ustawy zasadniczej i wyłonienia parlamentu w kolejnych wyborach. Decyzje prezydenta spotkały się z krytyką opozycji. Dzień po ogłoszeniu dekretów na kairskim Placu Tahrir i pod pałacem prezydenckim zebrały się tysiące przeciwników prezydenta. Rozpoczął się kolejny burzliwy okres protestów społecznych. Po przyjęciu deklaracji konstytucyjnej pod koniec listopada 2012 r. i pośpiesznym przyjęciu konstytucji przez wyższą izbę parlamentu zdominowaną przez islamistów, scena polityczna Egiptu została podzielona między

2 Na unijną pulę składały się 90 milionów euro w ramach programu SPRING, 163 milionów euro z Instrumentu Sąsiedztwa. Dodatkowo UE zapewniala nawet do $500 \mathrm{mln}$ euro pomocy makrofinansowej dla Egiptu (do $50 \mathrm{mln}$ euro w formie dotacji $1450 \mathrm{mln}$ euro w formie pożyczek preferencyjnych). 
grupę popierających Mursiego oraz świecką i liberalną opozycję reprezentowaną głownie przez Front Ocalenia Narodowego.

W Egipcie zauważalne były nowe formy wewnętrznej polaryzacji politycznej i napięcia między świeckimi i islamskimi siłami, ale także między grupami społecznymi dotkniętymi pogarszającą się sytuacją gospodarczą. W tym okresie UE zaangażowała się $\mathrm{w}$ dialog polityczny mający na celu zbliżenie skonfliktowanych stron.

Proponowane zapisy konstytucji rodzily kolejne protesty. Kwestionowano umieszczenie prawa koranicznego w konstytucji, a także regulacje dotyczące praw podstawowych, a przede wszystkim formuły funkcjonowania państwa. 9 grudnia 2012 r. Muhammad Mursi anuluje dekrety rozszerzające jego władzę. Pomimo niestabilnej sytuacji trwają przygotowania do referendum konstytucyjnego, które ostatecznie w dwóch turach przeprowadzone zostaje 15 i 22 grudnia 2012 roku.

\section{Zasada „obecności za wszelką cenę” w relacjach Unia Europejska-Egipt w okresie 2013-2014}

Rok 2013 dla Egiptu stanowił kolejny czas przełomu. 25 stycznia 2013 r. w drugą rocznicę wybuchu rewolucji egipskiej wybuchly gwałtowne zamieszki. Zwołane przez opozycję demonstracje odbywały się z powodu żądań ustąpienia prezydenta, zawieszenia obowiazzywania nowej konstytucji i ustanowienia płacy minimalnej. Unijna polityka wobec Egiptu z takim trudem ustalona na kolejnych stronach planów, komunikatów, programów, strategii rozsypała się jak domek $z$ kart. Nie nastąpił spodziewany i zapisany w Planie Działania postęp (ENP, 2014). Ze względu na rozwój sytuacji politycznej w Egipcie nie osiagnięto kluczowych zaleceń, co zawarto w sprawozdaniu z postępów w ramach EPS. Wyjątek stanowiło podpisanie konwencji regionalnej w sprawie paneurośródziemnomorskich preferencyjnych reguł pochodzenia.

W marcu 2013 roku Komisja Europejska wydała komunikat zatytułowany „Europejska Polityka Sąsiedztwa: pracując na rzecz silniejszego partnerstwa”, w którym stwierdzono, że przejście w kierunku silniejszych systemów demokratycznych jest złożone i czasochłonne, postęp nie zawsze jest liniowy, a wyniki są trudne do przewidzenia. Ocena sytuacji w Egipcie dokonana przez KE była następująca: „,władza została przekazana rządowi cywilnemu i stan wyjątkowy został zniesiony. Konstytucja została przygotowana i przyjęta w powszechnym referendum. Jednak ten proces był krytykowany przez opozycję, co doprowadziło do kryzysu politycznego i głębokich podziałów politycznych" (European Commission and High Representative, 2013). W odpowiedzi na tę sytuację uznano za właściwe podjęcie następujących działań: pogłębiona współpraca w obszarze wolności, bezpieczeństwa i sprawiedliwości, w szczególności poprzez dialogi na temat migracji, mobilności i bezpieczeństwa; promowanie wspólnego dobrobytu gospodarczego, w tym utrzymanie tempa negocjacji kompleksowych umów o wolnym handlu; kontakty międzyludzkie, w szczególności w zakresie promowania wymian młodzieży w ramach programu Erasmus Mundus; wzmocnienie społeczeństwa obywatelskiego; współpraca w dziedzinach, takich jak badania naukowe, przedsiębiorczość i MŚP, rolnictwo, transport, w tym usługi lotnicze i morskie, środowisko, zmiana klimatu, energia, telekomunikacja, budowanie zdolności administracyj- 
nych, kultura oraz dzielenie się wiedzą i wymiany ekspertów w zakresie przemian, wzmocnienie współpracy regionalnej.

Polityczna polaryzacja w Egipcie pogłębiła się wiosną 2013 r. Kryzys polityczny doprowadził w końcu czerwca do masowych demonstracji antyrządowych w całym państwie. Po ultimatum postawionym przez sily zbrojne, Mohamed Morsi został usunięty z urzędu prezydenckiego 3 lipca 2013 r. Unia Europejska po raz kolejny musiała skonfrontować swoje plany z destabilizacją sytuacji politycznej w Egipcie i przyjąć nowe scenariusze rozwoju wydarzeń. Popierając tak aktywnie Mursiego dyplomaci europejscy zrazili dużą część egipskich przedstawicieli ugrupowań radykalnych. Dotychczasowa polityka odbudowy relacji okazała się krotochwilna. Pomimo tego, przedstawiciele Unii na czele z Wysoką Przedstawiciel podjęli próbę współpracy ze wszystkimi stronami o pokojowe rozwiązanie kryzysu. Catherine Ashton odwiedziła Egipt 17 i między 29 a 30 lipca. Działania podjął także powołany w drugiej połowie 2011 roku Specjalny Przedstawiciel Unii Europejskiej w południowym regionie Morza Śódziemnego Bernardino Leona (Council decision, 2011). Oboje podkreślali przy różnych okazjach, że Egipt potrzebuje procesu transformacji, w który będą włączone wszystkie grupy polityczne, co umożliwi zorganizowanie wolnych i uczciwych wyborów oraz cywilnego rządu. W odpowiedzi na to, ugrupowania islamistyczne w Egipcie wysłały jasny sygnał do Catherine Ashton, że antyrządowe protesty będą trwały aż do przywrócenia porządku konstytucyjnego w państwie. Sytuacja w Egipcie stała się coraz bardzo napięta. Społeczeństwo dzieliło się prawie po połowie na zwolenników i przeciwników byłego prezydenta. Według tych ostatnich Mursi i Bractwo Muzułmańskie, z którego on się wywodzi, za swoich rządów zmonopolizowali władzę i nie rozwiązywali najważniejszych problemów. Koalicja ugrupowań islamistycznych popierających obalonego prezydenta wezwała do udziału w marszu protestacyjnym przeciwko władzom. W lipcu 2013 roku Ashton udaje się dotrzeć do obalonego prezydenta Mursiego i porozmawiać $\mathrm{z}$ nim prawie przez dwie godziny. Mursi przetrzymywany był w nieznanym miejscu i aby się z nim spotkać Ashton w nocy wyleciała z Kairu śmigłowcem w nieznanym kierunku. $W$ europejskich przekazach medialnych uznano to spotkanie jako swoista, rozpaczliwą próbę mediacji. W nadziei na możliwość wywarcia wpływu Catherine Ashton przyleciała do Egiptu nie znając dokładnego celu i pozostając w pewnym zakresie pozostawiona do dyspozycji nowego reżimu. Symbolika tego spotkania nabrała na znaczeniu dopiero w świetle kolejnych, dramatycznych wydarzeń w Egipcie, co uwidoczniło fakt, iż europejska mediatorka, pełna dobrej woli, nie miała wystarczających argumentów przekonywania. Szefowa unijnej dyplomacji przybyła do Kairu, apelując o włączenie do procesu transformacji politycznej w Egipcie członków Bractwa Muzułmańskiego. Stanęła ona na stanowisku, iż proces zmian musi doprowadzić, najszybciej jak to możliwe, do porządku konstytucyjnego, wolnych i uczciwych wyborów oraz utworzenia cywilnego rządu. Po stronie Bractwa Muzułmańskiego niespodziewanie opowiedziała się także Francja. Minister spraw zagranicznych Francji Laurent Fabius wezwał do uwolnienia obalonego przez armię prezydenta Egiptu Muhammada Mursiego oraz innych egipskich więźniów politycznych.

Od lipca pogłębił się chaos i przemoc w państwie. Fiasko ponieśli kolejni mediatorzy międzynarodowi, w tym także europejscy. W Kairze podczas demonstracji sierpniowych zginęło ponad 600 osób. Duża liczba ofiar była także w pozostałych miastach. 
23 września egipski sąd zakazał działalności Bractwa Muzułmańskiego, konfiskując jego aktywa. Rozpocząl się okres represji wobec jego członków. W okresie od sierpnia do grudnia 2013 r. konstytuanta przygotowywała nowy projekt ustawy zasadniczej w miejsce zawieszonej konstytucji po lipcowym zamachu stanu. Tymczasowy prezydent Adli Mansur ogłosił przeprowadzenie referendum konstytucyjnego w styczniu 2014 roku. Podczas niego obywatele mieli się wypowiedzieć za projektem pozbawionym odwołań do prawa koranicznego. Po rewizji konstytucji dokonanej przez egipskie władze tymczasowe, w styczniu 2014 r. odbyło się referendum w sprawie zatwierdzenia projektu konstytucji. Jednak frekwencja wyborcza była stosunkowo niska, a możliwości prowadzenia działań przedwyborczych przez opozycję były znacząco ograniczone. Wyniki głosowania ogłoszono 18 stycznia 2014 r. Nowa konstytucja weszła w życie, ale nadal trwały zamieszki na tle polityczno-społecznym. 25 stycznia 2014 r., w trzecią rocznicę wybuchu rewolucji z roku 2011, dochodzi do krwawych starć zwolenników tymczasowego rządu z islamistami. 27 stycznia pełniący obowiązki prezydenta Adli Mansur awansował generała Abdel'a Fatah Al-Sisi na stanowisko marszałka. Ponadto armia udzieliła mu mandatu do kandydowania w wyborach prezydenckich. Rozpoczął się okres kampanii przedwyborczej. Wybory monitorowało szereg organizacji międzynarodowych, w tym Unia Europejska, która krytycznie oceniła wiele elementów związanych z przygotowaniem wyborów (EU Election Observation Mission, 2014). Dla Unii dojście do władzy generała Sisiego to swoista porażka dotychczasowych unijnych wysiłków i wyzwanie dotyczące konieczności odnowienia ram współpracy i dialogu politycznego. Rozpoczyna się kolejny trudny okres w relacjach. Pomimo zapewnień wyrażonych w deklaracji po wyborach, że „Unia Europejska wyraża wolę bliskiej współpracy z nowymi władzami w Egipcie w ramach konstruktywnego partnerstwa, aby wzmocnić wzajemne relacje" (European Union, 2014). Realia tej współpracy okazały się dużo trudniejsze od dotychczasowych.

Kluczowa zmiana, która nastapiła $w$ podejściu UE do współpracy z Egiptem w okresie 2011-2014 wiąże się z uznaniem, że w przeszłości polityka opierała się na założeniu, że autorytaryzm stał się swoistą przeszkodą przeciwko terroryzmowi, fundamentalizmowi, nielegalnej migracji. Paradygmat dążenia do demokracji i stabilności, który podkreślany był w deklaracjach UE, był daleki od realiów prowadzenia polityki. Po roku 2012 nastapiło przeorientowanie podejścia w stosunkach dyplomatycznych. O ile wcześniej można było powiedzieć, że władze egipskie gwarantowały stabilność, ale nie demokrację, to po zmianach Unia toczyła dialog z egipskim partnerem w warunkach braku stabilności, z jeszcze mniejszymi niż wcześniej szansami na rozpoczęcie procesów demokratyzacyjnych. Istotnym unijnym posunięciem było postawienie nacisku na zaangażowanie się lokalnych podmiotów społeczeństwa obywatelskiego (podkreślone to zostało w ramach corocznego przeglądu EPS). Zwiększono możliwość dofinansowania inicjatyw i organizacji pozarządowych poprzez Instrument na rzecz Społeczeństwa Obywatelskiego (ang. Civil Society Facility). Utworzony także został Fundusz na rzecz Demokracji (ang. Endowment for Democracy) organ dysponujacy dotacjami skierowanymi do niezarejestrowanych organizacji pozarządowych i partii politycznych. Wprowadzono także zmianę regulacji istniejącej Europejskiej Inicjatywy na rzecz Demokracji i Praw Człowieka. Uznano, że rola społeczeństwa obywatelskiego ma decydujące znaczenie w ksztaltowaniu demokratycznej debaty oraz 
zapewnienia odpowiedzialności publicznej. Ten element był już obecny we wcześniejszych zapisach reorientujących politykę sąsiedztwa UE (Balfour, 2012; Cavatora, 2012), jednak po roku 2012 podjęto realne działania by wzmocnić wcześniej ustalone założenie.

Unia, stosując to nowe podejście, odchodzi od przyjętej zasady niestronniczości angażując się w politykę wewnętrzną państw trzecich. Wspierane są często małe, grupy nieformalne, stowarzyszenia i fundacje działające na rzecz przemian demokratycznych i praw człowieka. Te podmioty nie są przygotowane do konkurowania z podmiotami takimi jak Bractwo Muzułmańskie w kolejnych wyborach. Jednakże ich wpływ na kształtowanie określonych standardów reakcji jest duży. Przykładem tego nowego podejścia mogą być projekty współfinansowane przez Europejski Fundusz na rzecz Demokracji (EED), który uruchomiono na początku 2013 roku. Jego powstanie można postrzegać jako jeden z elementów długotrwałego procesu reformy zewnętrznych instrumentów Unii Europejskiej dotyczących promowania demokracji na świecie. Nowopowstały fundusz w założeniu miał uzupełniać inne formy działań UE pozwalające wpływać na sytuację w jej wschodnim i południowym sąsiedztwie (European Commission 2012c; Leininger, Richter, 2012). Jego celem stało się promowanie inicjatyw demokratyzacyjnych wpisanych w ramy budowy społeczeństwa obywatelskiego oraz wsparcia transformacji politycznej poprzez dotowanie osób i podmiotów, które miały utrudniony dostęp lub nie były w gronie potencjalnych beneficjentów środków pochodzących z innych unijnych źródeł (Ligor 2014). Szybki dostęp do środków, mniej zbiurokratyzowane procedury, elastyczność mechanizmu aplikowania to atuty nowego instrumentu. Jednakże skala realizowanych projektów jest mała, a możliwość weryfikacji realnego oddziaływania projektów ograniczona. Biorąc pod uwagę pierwsze dwa lata jego funkcjonowania, udzielone w ramach EED wsparcie, w odniesieniu do realnych potrzeb inwestowania $\mathrm{w}$ proces przemian w poszczególnych państwach sąsiedztwa, ma charakter symboliczny.

\section{Zakończenie}

Unia Europejska i Egipt oficjalnie uznają się wzajemnie za ważnych, strategicznych partnerów. W kształtowanych relacjach Egipt z Unią łączy i jednocześnie dzieli historia wspólnych doświadczeń, konieczność współpracy gospodarczej, a także wyzwania wynikające z zagrożeń dla bezpieczeństwa. Przez wiele lat, Unia Europejska za pomocą dostępnych instrumentów jej poszczególnych polityk starała się działać na rzecz demokratycznych przemian w Egipcie. Naciskała politycznie, a także poprzez zachęty mechanizmów gospodarczych do zmian. Przekazywała środki finansowe, które miały przyczynić się do koniecznych reform. Niewątpliwie nacisk na użycie instrumentów Unii w relacjach z Egiptem był podyktowany koniecznością zapewnienia Unii, jak i w szczególny sposób jej kilku państwom członkowskim niezbędnego wpływu na rzecz realizacji interesów gospodarczych i politycznych. Unia, wdrażając instrumenty poszczególnych polityk, nawoływała do przełomu na rzecz wpisanych w ramy jej podejścia strategicznego postulatów: dążenia do demokracji, poszanowania praw człowieka, swobód obywatelskich, budowy społeczeństwa obywatelskiego. Dąże- 
nia do zmian systemowych w państwach Afryki Północnej i Bliskiego Wschodu wyrosły na podwalinach buntu podsycanego przez promujące ideały i określone europejskie standardy państwa członkowskie i instytucje Unii. Poprzez wieloletnie wzmacnianie przekonania o możliwości budowy nowego porządku prawnego i ładu społecznego, Unia prowadząc $w$ wielowymiarowym zakresie politykę zewnętrzną przyczyniła się w pewnej mierze do wydarzeń, które nazwano arabską wiosną (Przybylska-Maszner, 2014). Wydarzenia roku 2011 zburzyly dotychczasowe więzi polityczne i podwaliny przez lata budowanej stabilności w relacjach. Kolejne burzliwe lata próby transformacji w Egipcie spowodowały konieczność budowy nowego podejścia do relacji obu partnerów. Konsekwencje zainicjowanych zmian, trudne do przewidzenia w momencie ich inicjowania, nie zawsze mogły być pozytywnie przyjęte przez stronę unijną.

Unia, zakładając zasadę zróżnicowania, w bilateralnym wymiarze współpracy musiała wyznaczyć zakres relacji z nowymi władzami w Egipcie. Unia wpisała zakres swych polityk w kształt ról, które chee pełnić na arenie międzynarodowej. Unijna polityka w dużej mierze była polityką 'na papierze', gdyż napotkała opór po stronie egipskiej. Bariery postawione przez nowe władze wymusiły na Unii odstepstwa od przyjętych założeń za cenę obecności i możliwości kształtowania gospodarczego wymiaru relacji.

Egipt jest dla UE niezwykle ważnym państwem strategicznym, partnerem dla ochrony jej interesów w regionie. Sytuacja gospodarcza i polityczna w Egipcie i szerzej w regionie wywiera wpływ na gospodarkę państw europejskich, europejski rynek pracy oraz tendencje społeczne w Europie. W obliczu zachodzących w Egipcie zmian państwa Unii Europejskiej i jej instytucje nie pozostają pozbawione instrumentów reakcji. Jednakże ich zastosowanie jest wielokrotnie udaremniane, bądź ograniczane. Nie jest to tylko efekt działań kolejnych rządów egipskich. Wynika to także z trzech dodatkowych powodów: mechanizmu odroczonej reakcji mechanizmu instytucjonalnego Unii, trudności w ustalaniu wspólnego stanowiska na płaszczyźnie dialogu międzyrządowego, trudnych interakcji z podmiotami trzecimi zaangażowanymi w Egipcie.

Pamiętać należy, że Unia ma ograniczone możliwości i legitymizację do oddziaływania na sytuację wewnętrzną Egiptu. Wdrażanie polityki sąsiedztwa to koordynacja działań w wielu sektorach, co już w założeniu jest arcytrudne. Prawdziwym wyzwaniem będzie długoterminowa pespektywa prowadzenia nowej odsłony dotychczasowej polityki na płaszczyźnie gospodarczej i przy udziale instrumentów politycznej manifestacji stanowiska. Polityka ta będzie jak dotychczas wypadkową interesów i siły przekonywania poszczególnych państw członkowskich. Dużo zależy od tego, czy za deklaracjami i strategicznymi ramami będą się kryły mechanizmy i działania zaakceptowane $\mathrm{w}$ ramach wdrażania przez partnera.

W Egipcie zapoczątkowana zmiana nie prowadzi do z góry wyznaczonego celu, nie jest ukierunkowana na osiągnięcie założeń wpisanych w liczne unijne dokumenty. Unijne decyzje podejmowane po roku 2012 wyznaczają nowy kierunek podejścia do relacji z partnerem egipskim, zarówno na niwie płaszczyzny regionalnej potwierdzonej w założeniach ENP, jak i poprzez szereg inicjatyw bilateralnych. Bardzo duże znaczenie dla Egiptu będzie miała sytuacja zewnętrzna, przemiany państw w regionie (Durac, 2013). Uwzględniając istniejący dorobek polityk i programów, UE była i jest zdeterminowana wspierać Egipt. Zapoczątkowany proces transformacji nie musi jednak ozna- 
czać działań na rzecz zapewnienia wartości, propagowanych przez państwa członkowskie Unii, pokoju, dobrobytu i poszanowania praw podstawowych. Próba wypracowania nowego podejścia strategicznego w regionie, uwzględniając tak ważnych partnerów jak Egipt, w ramach partnerstwa na rzecz demokracji i wspólnego dobrobytu nie wywoła natychmiastowych efektów. Pierwsze lata wdrażania tych założeń pokazały, iż podobnie jak w przypadku wcześniejszych inicjatyw, coraz trudniejsza staje się ich realizacja. Dynamika zmian w Egipcie jest bardzo duża. Istnieje realne zagrożenie powrotu do systemu niedemokratycznego. Równie pewne jest potencjalne przyzwolenie na współpracę UE z władzami autorytarnymi w wielu dziedzinach.

Jednym z podstawowych pytań, na które przedstawiciele państw członkowskich i Unii Europejskiej będą musieli odpowiedzieć w najbliższych latach jest to: czego oczekują od Egiptu i czy jest to możliwe, gdyż zgodne z intencjami współpracy ze strony partnera? Odrzucając balast politycznych iluzji i deklarowanych roli na arenie międzynarodowej, w odpowiedzi zawrzeć należy przekonanie o konieczności zapewnienia względnej stabilności politycznej w regionie, której gwarantem jest Egipt. Daje to nadzieję na utrzymanie przez Unię w relacjach z Egiptem ważnej pozycji głównego partnera gospodarczego opierając się na mechanizmie preferencyjnych regulacji handlowych. Na tej gospodarczej bazie obustronnych korzyści Egipt dla miałby stać się partnerem w przezwyciężaniu zagrożeń takich jak nielegalna migracja i terroryzm.

\section{Bibliografia}

Balfour R. (2012), Changes and Continuities In EU-Mediterranean Relations after the Arab Spring. w: An Arab Springboard for EU foreign policy?, eds. S. Biscop, R. Balfour, M. Emerson, Egmont Paper 54, Academia Press, January 2012, p. 27-36.

Cavatora F. (2012), Arab Spring: The Awekening of Civil Society. A General Overview, Institute European of Meditterranean, IEMed Paper.

Council decision 2011/424/CFSP appointing a European Union Special Representative for the Southern Mediterranean region, 18 July 2011.

Council of the European Union (2012), Joint Statement of the Eastern Partnership Foreign Ministers' Meeting, Brussels, 23 July 2012, 12862/12, PRESSE 348

Crawford G. (2013), EU human rights and democracy promotion in Africa: normative power or realist interests?, w: The European Union in Africa, Incoherent policies, asymmetrical partnership, declining relevance?, ed. M. Carbone, Manchester University Press, p. 142-164.

Durac V. (2013), The impact of external actors on the distribution of power in the Middle East: the case of Egypt, w: The Foreign Policies of the European Union and the United States in North Africa. Diverging or Converging Dynamics?, F. Cavatorta, V. Durac, Routledge, s. 72-87.

ENP Country Progress Report 2013 - Egypt, Brussels, 27 March 2014.

EU Election Observation Mission, Arab Republic of Egypt, Final Report Presidential Election, 26/27 May 2014.

EU-Egypt Task Force Co-chairs Conclusions, Cairo, 14 November 2012, http://www.enpi-info.eu/ library/content/eu-egypt-task-force-co-chairs-conclusions.

European Commission (2012a), Delivering on a new European Neighbourhood Policy, Joint communication to the European Parliament, the Council, the European Economic and Social Committee and the Committee of the Regions, JOIN (2012) 14 final, 14 May 2012. 
European Commission (2012b), The European Endowment for Democracy - Support for the Unsupported, Press Release, 12 November 2012.

European Commission and High Representative of the European Union for Foreign Affairs and Security Policy (2013), Joint communication to the European Parliament, the Council, the European Economic and Social Committee and the Committee of the Regions, European Neighbourhood Policy: Working towards a Stronger Partnership, Brussels, 20.3.2013. JOIN(2013) 4 final.

European Commission and High Representative of the European Union for Foreign Affairs and Security Policy (2014), Joint Staff Working Document, Implementation of the European Neighbourhood Policy in Egypt, Progress in 2013 and recommendations for action, Brussels. 27.3.2014, SWD(2014) 71 final.

European Union (2011), EU response to the Arab spring: the SPRING Programme, Fact Sheet, Memo 11/636, Brussels, 27 September 2011.

European Union (2012), EU-Egypt Task Force Fact Sheet, Memo A 515/12, Brussels, 14 November 2012.

European Union (2014), Declaration on behalf of the European Union on the presidential elections in Egypt, Brussels, 5 June 2014, 10649/1/14 REV 1, PRESSE 330.

Greenfield D., Balfour R. (2012), Arab Awakening: Are the US and EU Missing the Challenge?, Atlantic Council, June.

Joint Communication to the European Parliament, the Council, the European Economic and Social Committee and the Committee of the Regions, Eastern Partnership: A Roadmap to the autumn 2013 Summit, JOIN(2012) 13 final, 15.5.2012

Leininger J., Richter S. (2012), The European Endowment for Democracy between Wishful Thinking and Reality. Flexible and Unburocratic?, Brifing Paper, Deutche Institut fur Entwicklungspolitik, 1 November, http://papers.ssrn.com/sol3/papers.cfm?abstract_id=2480126.

Ligor M. (2014), European Endowment for Democracy - supporting the unsupported, „Europolity”, vol. 8 , nr 2 .

Przybylska-Maszner B. (red.) (2014), Operacje wojskowe Unii Europejskiej w Afryce, Poznań.

\section{Streszczenie}

Celem artykułu jest ukazanie zmiennych określających ramy polityki Unii wobec Egiptu w latach 2012-2014, a także analiza zakresu nowego podejścia do kształtowania wzajemnych relacji w ich wymiarze politycznym. Szczególna uwaga skupiona została na mechanizmie zastosowania instrumentów poszczególnych polityk unijnych na tle wydarzeń na scenie politycznej Egiptu. Powyższe rozważania pozwolą na przedstawienie wniosków dotyczących dalszych możliwości prowadzenia działań przez Unię Europejską w określonych ramach wspólpracy z Egiptem, biorąc pod uwagę konieczność ustalania wspólnych interesów, jak i wdrażania wypracowanego stanowiska.

Słowa kluczowe: relacje zewnętrzne UE, polityka zagraniczna UE, relacje UE-Egipt

Variables in the political relations between the European Union and Egypt after 2012

\section{Summary}

The paper attempts to indicate the variables that define the framework of EU policy towards Egypt in 2012-2014, and to analyse the scope of the new approach to mutual relations in terms of 
politics. Particular attention is given to the mechanism of various instruments applied by different EU policies and their implementation in the context of political developments in Egypt. These considerations allow the author to draw conclusions on the future possibilities for the European Union to continue its activities within the framework of cooperation in Egypt, taking into consideration the necessity to agree on common interests and to implement an adopted standpoint.

Key words: external relations of the EU, EU foreign policy, EU-Egypt relations 